\title{
Pengaruh Employee Engagement Terhadap Kesiapan Menghadapi Perubahan Oganisasi
}

\author{
Hotpascaman Simbolon \\ Universitas HKBP Nommensen, Medan. \\ Email : hotpascaman@mail.ugm.ac.id
}

\begin{abstract}
The aim of this study was for knowing the impact of employee engagement toward organizational change preparation. The sampling method used in this study was total sampling with 93 people. Hyothesis in this study were confirmedly accepted with statistically regression score 0.877 while the distribution of the data were normal categorization. The result of this study showed that facing the organization change, organization (on this term company) need an engaged employee toward the company.
\end{abstract}

\section{Keywords: Employee Engagement, Organization Change preparation}

\section{PENDAHULUAN}

Organisasi adalah kumpulan beberapa individu yang memiliki tujuan yang sama. Defenisi ini tidak terbatas pada sebuah kelompok, namun dapat ditarik pada sebuah lingkup yang lebih besar , dalam hal ini organisasi perusahaan. Perusahaan pada umumnya memiliki visi ke depan untuk bertahan, tidak hanya sebatas mencapai pangsa pasar namun juga mempertahankan pangsa pasar tersebut agar mampu bertahan.

Pangsa pasar termasuk di dalamnya trend yang berkembang dalam dunia bisnis, pada awalnya ditentukan oleh perusahan perusahaan lama dan besar. Sebagai contoh pada wal tahun 2000an pasar industry telekomunikasi banyak dikuasai dan di manage oleh perusahaan finlandia yaitu Nokia. Namun seiring dengan persaingan persaingan antara perusahaan yang memiliki bisnis sejenis, maka perusahaan Nokia tersebut tidak mengikuti adanya perubahan tuntutan dari pangsa pasar namun malah menjadi ikut dalam persaingan yang membuat perusahaan Nokia melepas unit bisnis telekomunikasinya pada perusahaan lebih besar.
Perubahan tuntutan pasar ini seakan menuntut adanya perubahan dari stuktural, sehingga adanya perubahan kebijakan dan sistem. Perubahan ini menjadi perubahan massive yang terjadi pada badan organisasi perusahaan.

Fernandez dan Renay (2006) menyebutkan bahwa sebagai langkah awal proses perubahan, organisasi perlu memastikan bahwa setiap individu memiliki kebutuhan dan kesiapan untuk berubah. Menurut Armenakis et al. (1993, dalam Ikawati 2015), salah satu proses awal yang harus dilakukan dalam perubahan organisasi adalah proses pengukuran (assessmen) untuk mengetahui sejauhmana kesiapan pegawai. Asesmen tersebut bertujuan untuk membantu pimpinan mengidentifikasi gap antara harapan mereka dan anggota organisasi yang lainterkait inisiatif perubahan

Armenakis, et al (1993) dalam penelitiannya juga menyatakan bahwa kesiapan karyawan merupakan pendorong tercapainya efektivitas perubahan organisasi. Jika karyawan tidak percaya bahwa perubahan tersebut diperlukan atau karyawan melihat bahwa perusahaan tidak mampu melakukan perubahan tersebut, maka proses perubahan akan mengalami kegagalan. 
Penelitian McKinsey (2010) menunjukkan hanya sekitar 30 persen dari program transformasi skala besar yang berhasil mencapai target yang diharapkan, sedangkan sekitar 70 persen mengalami kegagalan. Penelitian lain yang dilakukan oleh Schaffer dan Thompson (1992, dalam Song, 2009) menunjukkan hanya sebanyak 10 persen perusahaan yang berhasil mengimplementasikan program perubahan Total Quality Management sedangkan 63 persen lainnya gagal meraih perbaika kualitas. Dari berbagai faktor yang menyebabkan kegagalan transformasi, factor manusia (SDM) dan faktor organisasi yang paling mendominasi.

Perubahan organisasi ini menurut teorinya dibutuhkan oleh semua organisasi (Cummings and Worley, 2008). PT X merupakan salah satu group perusahaan yang bergerak di bidang perkebunan, alat berat dan pengolahan hasil perkebunan. Pada dasarnya group ini merupakan perusahaan yang dibangun dari rekanan keluarga, sehingga dalam melakukan perekrutan karyawan cenderung masih menitikberatkan pertimbangan yang belum memgikuti kaidah peraturan manajemen sumber daya manusia yang ideal. Pada Tahun 2014, seiring dengan tuntutan dari peraturan pemerintah, PT X mengharuskan semua administrasi dan aturan peraturan mengikuti kaidah ISO agar perijinan bisnis perusahaan juga dapat dilaksanakan. Untuk mengakomodir tuntutan tersebut, PT X memulai perubahan birokasi yang lebih tersistematis, dimulai dari seleksi, internal audit yang mengacu pada standa ISO serta proses retensi.

DI sisi lain, sebagaimana diungkapkan dalam hasil wawancara pada bagian SDM PT X, Tuntutan perubahan organisasi yang dialami oleh perusahaannya dimulai dari kesiapan kapasitas manusia dalam menghadapi perubahan administrasi dan manajemen membuat pergerakan organisasi lambat. Belum lagi persepsi pegawai yang kurang memandang positif terhadap tuntutan yang sangat cepat cenderung pesimistis dan enggan untuk bekerja dengan maksimal.

Hingga saat ini, Pada PT X belum pernah mengadakan survey untuk melihat kesiapan perubahan baik pada level organisasi ataupun individu. Rafferty et al. (2013) dalam peneliriannya mengidentifikasi beberapa anteseden kesiapan untuk berubah pada level individu. Anteseden tersebut terutama berasal dari konteks internal organisasi, yaitu persepsi individu terhadap konteks-konteks organisasional (komunikasi, dukungan organisasi, keselarasan nilai dan nilai-nilai organisasi).

Menurut Holt et al (2007) terdapat 3 (tiga) faktor yang mempengaruhi seorang karyawan akan memiliki kesiapan dalam menghadapi perubahan yaitu isi perubahan itu (change content), proses pelaksanaan perubahan (change process), dan kondisi lingkungan (organizational context). Secara ilmiah ketiga faktor ini merujuk pada faktor eksternal dan berada pada kebijakan dan pelaksanaannya. Faktor ini bagi penyusun didukung oleh penelitian yang dilakukan oleh Ikawati (2015), penelitiannya mengemukakan bahwa iklim organisasi mampu mempengaruhi nilai nilai kesiapan seorang karyawan dalam menghadapi perubahan.

Pada level individu, Amenakins \& Harris (2009). Juga mengemukakan beberapa faktor yang menentukan perubahan keyakinan seorang karyawan untuk mendukung perubahan, salah satunya adalah personal valance, yaitu adanya keyakinan dari seorang karyawan akan perubahan akan memberikan keuntungan secara personal bagi dirinya. Secara implikasi, seorang karyawan akan mempertimbangkan dan mendukung sebuah perubahan apabila dirinya menerima manfaat secara individu. 
Proses penerimaan dan pertukaran ini juga memiliki kesamaan konsep dengan SET (Social Exchange Theory), di mana hubungan yang terjadi antara karyawan dan perusahaannya terjadi dari serangkaian interaksi yang berevolusi dengan waktu dengan adanya rasa saling menguntungkan dan saling setia selama rentang kondisi tertentu.

Pada kondisi yang lebih intens, konsep SET ini merupakan dasar untuk munculnya rasa keterikatan antara karyawan dengan perusahaan. Konsep keterikatan secara psikologis ini disebut juga Employee engagement. Menurut Robinson, Perryman dan Hayday (2004 selanjutnya akan disebut Robinson et al). Employee engagement merupakan sikap positif yang dimiliki karyawan terhadap organisasi.Karyawan yang engaged akan menunjukkan perilaku untuk meningkatkan bisnis dan performa organisasi.

Secara psikologis, Kahn (1990) memberi definisi bahwa engagement merupakan adanya kehadiran ikatan secara psikologis ketika bekerja dan melakukan peranan di lingkup organisasi.

Sebagaimana kesiapan perubahan organisasi yang telah disebutkan sebelumnya dapat dipengaruhi oleh adanya dukungan organiasi, employee engagement mampu memberikan kontribusi yang berhubungan dengan persepsi akan dukungan organisasi terhadap karyawan (Ram \& Prabhakar, 2011). Sehingga dalam memertimbangkan dan menerima perubahan, maka karyawan yang memiliki keterikatan dengan perusahaan akan memiliki persepsi yang positif terhadap dukungan organisasi agar perubahan terlaksana sesuai dengan situasi yang diterima oleh perusahaan.

Dari pemaparan yang sudah diungkapkan leh peneliti dapat dilihat bahwa terdapat faktor yang mempengaruhi kesiapan seorang karyawan dalam menghadapi perubahan akan ditentukan oleh banyak hal, baik dari internal ataupun eksternal, namun sampai saat ini belum ada studi literature yang mendukung dengan pasti adanya pengaruh employee engagement terhadap kesiapan.

Berneth (2004) menyatakan bahwa kesiapan adalah suatu realisasi pikiran di dalam individu yang mengalami proses keberterimaan terhadap suatu perubahan. Defenisi lain dari kesiapan adalah derajat pandangan yang dimiliki seseorang akan perubahan ataupun keyakinan dari sesorang bahwa perubahan akan memberikan dampak bagi merekasecara keseluruhan.

Pada konteks organisasi, menurut Huy (dalam Prianto 2008) kesiapan indivifu untuk berubah diartikan sebagai kesediaan individu (dalam hal ini karyawan) untuk berpartisipasi dalam kegiatan yang dilaksanakan oleh organisasi baik sebelum dan selama perubahan organisasi berlangsung.

Holt, Armenakis, Feild \& Harris (2007) - selanjutnya akan disebut Hot et all- mendefinisikan kesiapan individu untuk berubah sebagai sikap komprehensif yang secara simultan dipengaruhi oleh isi (apa yang berubah), proses (bagaimana perubahan diimplementasikan), konteks (lingkungan dimana perubahan terjadi), dan individu (karakteristik individu yang diminta untuk berubah) yang terlibat di dalam suatu perubahan. Kesiapan individu untuk berubah secara kolektif merefleksikan sejauh mana individu atau sekelompok individu cenderung untuk menyetujui, menerima, dan mengadopsi rencana spesifik yang bertujuan untuk mengubah keadaan saat ini.

Dari defenisi sebelumnya dapat disimpulkan bahwa pengertian dari kesiapan menghadapi perubahan organisasi atau kesiapan berubah sebagai sikap yang dimiliki oleh individu (dalam hal ini karyawan) dengan mempertimbangkan konteks, isi, ataupun sistem dalam menerima suatu kondisi 
perubahan baik sesaat terjadinya dan selama proses perubahan berlangsung.

Dimensi yang dipakai dalam penelitian ini, didasarkan pada troei yang dikemukakan oleh Hot et al (2007), yaitu

1. Appropriateness. Merupakan keyakinan individu bahwa perubahan yang diusulkan akan tepat bagi organisasi dan organisasi akan mendapatkan keuntungan dari penerapan perubahan. Dimensi ini menjelaskan bahwa Individu meyakini adanya alasan yang logis, kebutuhan, serta berfokus pada manfaat dari perubahan yang diusulkan bagi perusahaan.

2. Change Efficacy. Merupakan rasa percaya diri dari individu untuk menghadapi perubahan. Pada dimensi ini berisi keyakinan individu tentang kemampuannya untuk menerapkan perubahan yang diinginkan, seperti mempunyai keterampilan seta sanggup untuk melakukan tugas yang berkaitan dengan perubahan. Dengan kata lain, karyawan merasa bahwa ia memiliki kemampuan dan dapat menyelesaikan tugas dan aktivitas yang berhubungan dengan pelaksanaan perubahan yang diusulkan.

3. Management Support. Merupakan keyakinan dari individu terhadap manajemen yang menaungi semua karyawan, atau dengan kata lain para pimpinan dan manajemen yang terkait memiliki komitmen serta mendukung perubahan.

4. Personal benefit. Merupakan keyakinan dari karyawan dimana secara personal dirinya mendapatkan keuntungan pada saat perubahan di implementasikan

Armenakis \& Harris (2009) mengidentifikasi lima faktor utama yang dapat merubah keyakinan diri karyawan untuk mendukung perubahan yaitu: a) Discrepancy, yaitu keyakinan bahwa perubahan itu diperlukan oleh organisasi

b) Aappropriateness yaitu adanya keyakinan bahwa perubahan spesifik yang dilakukan merupakan cara yang tepat untuk mengatasi masalah yang dihadapi

c) Efficacy yaitu rasa percaya bahwa karyawan dan organisasi mampu mengimplementasikan perubahan

d) Principal support yaitu persepsi bahwa organisasi memberikan dukungan dan berkomitmen dalam pelaksanaan perubahan dan mensukseskan perubahan organisasi

e) Personal valance yaitu keyakinan bahwa perubahan akan memberikan keuntungan personal bagi karyawan.

Secara psikologis, Kahn (1990) memberi definisi bahwa engagement merupakan adanya kehadiran ikatan secara psikologis ketika bekerja dan melakukan peranan di lingkup organisasi. Gallup (dalam Martha, 2011), mendefinisikan employee engagement sebagai sebuah ikatan yang terjadi antara karyawan dan organisasi (tempat bekerja), sehingga karyawan menunjukkan kepedulian terhadap keberlangsungan bisnis. Cropanzano dan Mitchel (2005), juga mengungkapkan bahwa konsep employee engagement dapat diselaraskan dengan teori SET (Social Exchange Theory), di mana hubungan yang terjadi antara karyawan dan perusahaannya terjadi dari serangkaian interaksi yang berevolusi dengan waktu dengan adanya rasa saling menguntungkan dan saling setia selama rentang kondisi tertentu. Cropanzano (dalam Cropanzano, Prehar \& Chen, 2002) memberi contoh dalam menggambarkan SET yaitu ketika seorang menerima pemenuhan dari segi ekonomis dan sosial dari perusahaan maka individu akan merasakan adanya keinginan untuk membalas atas pemenuhan perusahaan tersebut. 
Employee engagement memiliki hubungan dengan produktivitas, employee retention, keamanan dan bahkan kepuasan konsumen (Buckingham \& Coffman, 1999; Little \& Little 2006). Perilaku yang menjadi anteseden dalam employee engagement dapat dilihat dari keseluruhan komitmen, minat, keterlibatan, antusiasme individu pada situasi bekerja, yang sesuai dengan tujuan organisasi serta diprediksi mampu meningkatkan efektivitas organisasi tersebut. (Macey \& Schenider, 2008).

Employee engagement berbeda dengan komitmen organisasi. Komitmen organisasi berhubungan dengan sikap dan kedekatan dengan oganisasi. Sedangkan engagement bukan sikap melainkan tingkatan yang dimana indivdu memiliki perhatian lebih dalam menjalankan peran mereka di lingkungan pekerjaan. (Martha, 2011).

Terdapat 3 (tiga) kategori employee engagement, yaitu:

1. Engaged. Engaged merupakan karyawan yang mengetahui ekspektansi peran keberadaan mereka, serta peduli akan organisasi atau perusahaan tempat ia bekerja. Diperkirakan performa yang mereka miliki berada di atas rata-rata.

2. Non Engaged. Non Engaged merupakan karyawan yang berfokus pada pekerjaan yang dimiliki, dengan kurang memperhatikan tujuan besar dari organisasi. Karyawan ini cenderung hanya ingin menyelesaikan keseharian pekerjaan.

3. Actively Disengaged. Actively Disengaged merupakan karyawan yang tidak berfokus pada pekerjaannya dan memiliki perasaan negatif terhadap pekerjaan yang dimiliki. Bahkan karyawan dengan jenis engagement ini diprediksi akan merusak dan menyebarkan pengaruh buruk pada karyawan ataupun fungsi organisasi tempat ia bekerja. Schaufeli, Bakker, dan Salanova (2006) menemukan adanya hubungan disengangement yang dialami oleh karyawan dengan peningkatan burnout yang berujung pada munculnya turnover intention.

Penyusun menyimpulkan bahwa employee engagement adalah keterikatan karyawan dengan perusahaan dengan menunjukkan perilaku antusiasme yang formal dalam standar organisasi, memiliki perhatian lebih dalam menjalankan perannya dalam meningkatkan efektivitas organisasi (perusahaan).

\section{METODE}

Variabel Dependen (Y) dalam penelitian ini adalah Kesiapan untuk berubah Variabel Independen (X) dalam penelitian ini adalah Employee engagement

Kriteria dalam populasi ini adalah karyawan tetap pada usia produktif dengan masa bekerja minimal 2 tahun. Pemilihan criteria 2 tahun ini didasarkan pada teori bahwa lama seorang karyawan mampu memahami iklim budaya dan memiliki keterikatan adalah sebanyak 2 tahun.

Instrumen yang dipakai dalam penelitian ini memggunakan skala sikap.

1) Instrument Skala kesiapan menghadapi perubahan.

Skala Kesiapan menghadapi perubahan (kesiapan berubah) menggunakan dimensi yang diungkapkan oleh Holt et $\mathrm{Al}$ (2007), yaitu Appropriate Efficacy, supporting personal favor.

2) Instrumen Skala Employee Engagement.

Skala employee engagement ini berlandaskan pada teori yang dikemukakan oleh Gallup. Skala ini memiliki 12 aitem indikator employee engagement. Adapun reliabilitas dalam skala ini pada penelitian terdahulu adalah sebesar 0.819 (Simbolon, 2012)

Beberapa persyaratan harus dipenuhi sebelum melakukan uji hipotesis, adalah terpenuhinya uji asumsi. Maka uji asumsi klasik yang 
digunakan dalam penelitian ini terdiri dari uji normalitas uji linieritas.

Uji hipotesa yang digunakan dalam penelitian ini adalah regresi linier sederhana. Hal ini ditujukan untuk melihat pengaruh dari variabel $J o b$ Characteristic terhadap variabel Turnover Intention.

\section{HASIL}

Data yang digunakan dalam penelitian ini adalah data Sekunder yang berasal dari perusahaan dan data primer yang berasal dari penyebaran skala.

Faktor jenis kelamin perlu mendapat perhatian berkaitan dengan kemampuan Karyawan dalam menjalankan pekerjaan dan perilaku Karyawan. Distribusi responden menurut jenis kelamin dapat dilihat pada Tabel 1 .

Tabel 1. Deskripsi Responden tentang Jenis Kelamin

\begin{tabular}{ccc}
\hline $\begin{array}{c}\text { Jenis } \\
\text { Kelamin }\end{array}$ & Jumlah & \% \\
\hline Wanita & 14 & 15,05 \\
\hline Pria & 79 & 84,95 \\
\hline Total & $\mathbf{9 3}$ & $\mathbf{1 0 0}$ \\
\hline
\end{tabular}

Distribusi karaktersitik responden berdasarkan masa kerja anak buah kapal ditunjukan pada Tabel 2. seperti berikut:

Tabel 2. Deskripsi Responden tentang Masa

\begin{tabular}{ccc} 
Kerja & & \\
\hline Masa Kerja & Jumlah & \% \\
\hline$<1$ tahun & 4 & 4,30 \\
\hline $1-2$ tahun & 10 & 10,75 \\
\hline $3-5$ tahun & 35 & 37,63 \\
\hline $6-10$ tahun & 20 & 21,50 \\
\hline$>10$ tahun & 24 & 25,80 \\
\hline Total & $\mathbf{9 3}$ & $\mathbf{1 0 0}$ \\
\hline
\end{tabular}

Berdasarkan tabel diatas menunjukan sebagian besar karyawan yang masa kerjanya diatas 10 tahun mendominasi sebanyak 25,80persen, setelah itu anak buah kapaldengan masa kerja antara 6 tahun hingga 10 tahun sebanyak 21,50 persen. Sedangkan karyawan dengan masa kerja 1 tahun hingga 2 tahun memiliki persentase yang paling rendah yaitu sebesar 10,75 persen.

Berdasarkan masa kerjanya para karyawan PT.X telah mengabdikan dirinya dalam kurun waktu yang lama. Kondisi tersebut menunjukan loyalitas yang tinggi dari para karyawan di lingkungan pada segi waktu.

Tabel 3. Distribusi Frekuensi engagement

\begin{tabular}{cccc}
\hline Kategori & $\begin{array}{c}\text { Engage } \\
\text { ment }\end{array}$ & $\begin{array}{l}\text { Peserta } \\
\text { sesuai } \\
\text { kategori }\end{array}$ & $\begin{array}{c}\text { Persen } \\
(\%)\end{array}$ \\
\hline Tinggi & $\begin{array}{c}\mathrm{X}> \\
86.518\end{array}$ & 17 & 18.3 \\
\hline \multirow{5}{*}{ Sedang } & $\begin{array}{c}80.177< \\
\mathrm{X}<\end{array}$ & 59 & 63.4 \\
& 56.802 & & \\
\hline Rendah & $\begin{array}{c}\mathrm{X}< \\
56.802\end{array}$ & 17 & 18.3 \\
\hline
\end{tabular}

Sebaran data engagement dalam penelitian ini dapat dilihat dalam table 3 diatas, dimana terdapat $18.3 \%$ atau sekitar 17 orang yang memiliki menilai engagement dalam kategori tinggi, terdapat $63.4 \%$ atau sekitar 59 orang yang memiliki engagement dalam kategori sedang, serta terdapat $18.3 \%$ atau sekitar 17 orang yang memiliki engagement dalam kategori rendah.

Sebaran data Kesiapan Menghadapi perubahan Organisasi dalam penelitian ini dapat dilihat dalam table 4 dimana terdapat $15 \%$ atau sekitar 14 orang yang memiliki menilai Kesiapan Menghadapi perubahan Organisasi dalam kategori tinggi, terdapat $72 \%$ atau sekitar 67 orang yang memiliki Kesiapan Menghadapi perubahan Organisasi dalam kategori sedang, serta terdapat $13 \%$ atau sekitar 12 orang yang memiliki Kesiapan Menghadapi perubahan Organisasi dalam kategori rendah. 
Tabel 4. Distribusi Frekuensi Kesiapan Menghadapi perubahan Organisasi

\begin{tabular}{cccc}
\hline Kategori & $\begin{array}{c}\text { Kesiapan } \\
\text { peruba-han } \\
\text { Or-ganisasi }\end{array}$ & $\begin{array}{c}\text { Peserta } \\
\text { sesuai } \\
\text { kategori }\end{array}$ & $\begin{array}{c}\text { Persen } \\
(\%)\end{array}$ \\
\hline TInggi & $\begin{array}{c}\mathbf{X}> \\
84.727\end{array}$ & 14 & $15 . \%$ \\
\hline Sedang & $\begin{array}{c}77.2527< \\
\mathbf{X}<84.727\end{array}$ & 67 & $72 \%$ \\
\hline Rendah & $\begin{array}{c}\mathbf{X}< \\
77.2527\end{array}$ & 12 & $13 \%$ \\
\hline
\end{tabular}

Uji normalitas digunakan untuk mengetahui data terdistribusi dengan normal atau tidak. Analisis parametrik seperti regresi linier mensyaratkan bahwa data harus terdistribusi dengan normal. Uji normalitas menggunakan metode Kolmogorov-Smirnov Z. Metode pengambilan keputusan dengan menggunakan kriteria Data berdistribusi normal apabila probabilitas $>0,05$ dan Data tidak berdistribusi normal apabila probabilitas $<0,05$.

Tabel 5. Uji Normalitas Data

\begin{tabular}{lll}
\hline & $\begin{array}{l}\text { Kesiapan } \\
\text { perubahan } \\
\text { organisasi }\end{array}$ & Engagement \\
\hline $\begin{array}{l}\text { Kolmogorov- } \\
\text { Smirnov Z }\end{array}$ & 1.275 & .455 \\
$\begin{array}{l}\text { Asymp. Sig. }(2- \\
\text { tailed) }\end{array}$ & .078 & .986 \\
\hline
\end{tabular}

Dari table 5 dapat diketahui bahwa kedua data variabel tersebut dapat dinyatakan bahwa berdistribusi normal. $\mathrm{Hal}$ ini diketahui dari nilai asumsi nilai signifikansi diatas 0.05 .

Adapun uji hipotesa yang digunakan dalam penelitian ini adalah menggunakan uji regresi linier dengan melihat ketetapan model fit melalui uji t. Hasil uji regresi dapat dilihat pada tabel berikut ini :

Tabel 6. Hasil uji korelasi dan regresi data engagement dan kesiapan menghadapi perubahan organisasi

\begin{tabular}{|c|c|c|c|c|}
\hline Model & $\mathrm{R}$ & $\begin{array}{c}\mathrm{R} \\
\text { Square }\end{array}$ & $\begin{array}{l}\text { Adjusted R } \\
\text { Square }\end{array}$ & $\begin{array}{c}\text { Sig. F } \\
\text { Change }\end{array}$ \\
\hline 1 & $.937^{\mathrm{a}}$ & .877 & .876 & 0.00 \\
\hline
\end{tabular}

Tabel 6 menunjukkan bahwa variabel engagement memiliki korelasi yang siginifikan dengan data kesiapan menghadapi perubahan organisasi. Dengan perubahan $\mathrm{R}$ square sebesar 0.877. sehingga dengan data ini menunjukkan bahwa Engagement berpengaruh ataupun berkontribusi sebesar $87,7 \%$ terhadap kesiapan mengahadpi perubahan Organisasi.

Adapun persamaan garis regresi yang dihasilkan pada data ini adalah :

$$
\mathrm{Y}=64.108+0.236 \mathrm{x}
$$

Persamaan ini memiliki arti bahwa setiap penambahan pengaruh pada data $\mathrm{X}$ (dalam hal ini data engagement) maka, diperkirakan akan terdapat penambahan data sebesar 0.236 pada data Y (dalam hal ini kesiapan menghadapi perubahan organisasi) dengan total data sebesar 64.344.

\section{DISKUSI}

Berdasarkan hasil pengujian hipotesis dengan jumlah data sebanyak 93 responden, ternyata hipotesis alternatif yang diajukan, secara signifikan dapat diterima. Hal ini mengacu pada nilai signifikansi sebesar 0.000 dan nilai $\mathrm{R}$ square sebesar 0.877 . Hasil penelitian ini konsisten dengan beberapa hasil penelitian dan teori bahwa ada beberapa variabel yang dapat mempengaruhi Kesiapan mengahadpi perubahan organisasi karyawan adalah yaitu engagement.

Hasil penelitian ini memprediksi terdapat pengaruh positif yang diberikan oleh engagement karyawan terhadap kesiapan karyawan dalam menghadapi perubahan organisasi. Data menunjukkan bahwa semakin bertambah pengaruh engagement karyawan maka diperkirakan bahwa karyawan akan 
semakin siap dalam menghadapi perubahan baik dalam dan luar organisasi pada PT X.

Pada level individu, Amenakins \& Harris (2009). mengemukakan beberapa faktor yang menentukan perubahan keyakinan seorang karyawan untuk mendukung perubahan, salah satunya adalah personal valance, yaitu adanya keyakinan dari seorang karyawan akan perubahan akan memberikan keuntungan secara personal bagi dirinya. Secara implikasi, seorang karyawan akan mempertimbangkan dan mendukung sebuah perubahan apabila dirinya menerima manfaat secara individu. Proses penerimaan dan pertukaran ini juga memiliki kesamaan konsep dengan SET (Social Exchange Theory), di mana hubungan yang terjadi antara karyawan dan perusahaannya terjadi dari serangkaian interaksi yang berevolusi dengan waktu dengan adanya rasa saling menguntungkan dan saling setia selama rentang kondisi tertentu. konsep SET ini merupakan dasar untuk munculnya rasa keterikatan antara karyawan dengan perusahaan. Konsep keterikatan secara psikologis ini disebut juga Employee engagement. Menurut Robinson, Perryman dan Hayday (2004 selanjutnya akan disebut Robinson et al). Employee engagement merupakan sikap positif yang dimiliki karyawan terhadap organisasi. Karyawan yang engaged akan menunjukkan perilaku untuk meningkatkan bisnis dan performa organisasi.

\section{SIMPULAN}

Hipotesa dari penelitian dengan menggunakan 93 data responden ini dinyatakan diterima, dimana terdapat pengaruh positif eengagement terhadap kesiapan menghadapi perubahan organisasi pada PT X dengan signifikansi 0.00 . dengan nilai $\mathrm{R}^{2}$ sebesar 0.877 . Adapun bentuk pengaruh yang dimiliki dari data hasil penelitian adalah positif, sehingga bila terdapat peningkatan data engagement maka terdapat peningkatan pada data kesiapan menghadapi perubahan organisasi.

Kategorisasi untuk data variabel engagement berada pada tingkatan sedang yaitu sebanyak 59 orang (63.4\%) dan kategorisasi data variabel kesiapan menghadapi perubahan organisasi berada pada tingkatan sedang sebanyak 67 orang (72\%).

Persamaan regresi yang dibentuk pada 93 data hasil penelitian ini adalah $\mathrm{Y}$ $=\mathrm{Y}=64.108+0.236 \mathrm{x}$.

\section{DAFTAR PUSTAKA}

Armenakis, A.A., Harris, S.G., \& Mossholder, K.W. (1993). Creating readiness for change. Human Relations, 46 (6), 681-183

Berneth J. (2004). Expanding of our understanding of change message. Human Resource Development review, 3 (1), 36-52

Cummings, T.G. \& Worley, C.G. 2008. Organizational Development and Change 9th edition. Ohio: Maso

Cropanzano, R. \& Mitchell, M.S. (2005). Social exchange theory: an interdisciplinary review", Journal of Management, 31: 874-900

Fernandez, S. dan Raney, H.G. 2006. Managing Succesfull Organizational Change in the Public Sector. Public Administration Review (MarchApril): 168-176.

Ikawati, A,P.D (2015). Analisis pengaruh kepemimpinan transformasional dan iklim psikologis pada kesiapan untuk berubah: studi pada pegawai secretariat jendral kementrian keuangan keuangan. (Unpublished Master's Thesis). 
Universitas Gadjah Mada, Jogjakarta

\begin{tabular}{|c|c|c|}
\hline $\begin{array}{l}\text { Simbolon, H. } \\
\text { Organizational } \\
\text { hubungan empl } \\
\text { dan turnov }\end{array}$ & $\begin{array}{l}\text { (2012). } \\
\text { citizenshi } \\
\text { loyee eng } \\
\text { ver i }\end{array}$ & $\begin{array}{l}\text { Peran } \\
\text { ip dalam } \\
\text { gagement } \\
\text { intention. }\end{array}$ \\
\hline Unpublished & Master's & Thesis. \\
\hline $\begin{array}{l}\text { Universitas } \\
\text { Jogjakarta. }\end{array}$ & Gadjah & Mada, \\
\hline
\end{tabular}

Little, B. \& Little P. (2006). Employee Engagement: Conceptual Issues. Journal of Organizational culture, communications and conflict, 10 (1), 111-120

Macey, W., \& Schneider, B. (2008). The meaning of employee engagement. Industrial and Organizational Psychology: Journal perspectives on science and practice, 1 (1), 330

Martha. L. (2011). Analisis pengaruh kepemimpinan terhadap employee engagement: studi kasus pada Pt. Ace Hardware, tbk. (Unpublished Master's Thesis). Universitas Atmajaya, Jakarta

Oktaviany, R. (2012). Sosialisasi terhadap perubahan sebagai intervensi untuk meningkatkan motivasi dalam mendukung kesiapan perubahan (suatu studi pada kasus PT XYZ). Unpublished Master's Thesis. Universitas Indinesia, Jakarta

Robinson D., Perryman S., \& Hayday S. (2004). The Drivers of Employee Engagement Report 408. UK: Institute for Employment Studies

Schaufeli, W. B., Bakker, A., \& Salanova, M. (2006). The measurement of work engagement with a short questionnaire: A cross-national study. Educational and Psychological Measurement, 66, 701-716. 